\title{
ANALYSIS OF THE RELATIONSHIP BETWEEN CREDIT RISK AND BANK PERFORMANCE OF SOME COMMERCIAL BANKS IN GHANA
}

\author{
Joseph Acquah ${ }^{1}$, Yusif Arthur ${ }^{2}$, Damianus Kofi Owusu ${ }^{3}$ \\ ${ }^{\prime}$ CEMBA, Department of mathematics, Wesley Girls' High School, Cape Coast, Ghana, jakwameato@gmail.com \\ ${ }^{2}$ PhD Student, Department of Business Studies, Cape Coast Technical University, Cape Coast, Ghana \\ ${ }^{3} \mathrm{PhD}$ Student, Department of Mathematical Sciences, University of Mines and Technology, Tarkwa, Ghana, \\ dkowusu@st.umat.edu.gh \\ *Correspondence: damian.kowusu@gmail.com ;Tel.: +233(0)241620365
}

\begin{abstract}
This study analysed the relationship between credit risk and bank financial performance of selected commercial banks in Ghana for the period 2010 - 2014, using the banks respective financial statements. The study employed the quantitative research approach. The sample was Ghana Commercial Bank Limited, Zenith Bank Limited, UT Bank and Ecobank Plc. These four banks were selected using stratified random sampling technique. The data were primarily secondary and quantitative in nature. Both descriptive and inferential statistics were used to analyse the data. When the banks were compared, Ghana Commercial Bank Limited was found to be more liquid than Zenith Bank Limited. That of Zenith bank was also higher than UT bank and Ecobank Plc .However, profitability indicators showed that Zenith Bank Limited and Ecobank Plc utilised its assets better than Ghana Commercial Bank Limited and UT bank resulting in the two banks higher scores over the period. The findings show further that Ghana Commercial Bank Limited showed higher ratios for investment in the future while Zenith Bank Limited showed higher ratios of higher dividend immediately. However, Zenith Bank Limited capital adequacy level was far higher than the legal requirement of Banking sector while its counterparts fell slightly below it in terms of average. Based on the main findings and conclusions, it is recommended that Ghana Commercial Bank Limited should find a means of reducing its expenditure, introducing prudent assets management, should be cautious when assisting government in time of economic difficulty, and operate as an independent entity.
\end{abstract}

Keywords: Credit risk, Bank financial performance, Loan default payment

\section{INTRODUCTION}

An economy with a robust financial wellbeing plays an important role in its development [23] since its failure can disrupt the advancement of the nation. The financial resources of an organisation are the company's capacity to create innovative resources, from day-to-day setup over a specified period of time and it is guarded from net income and cash from operation. When an organisation, for instance the bank generates enough resources, it uses these resources to generate more resources by the processing of giving out loans. The likelihood of bringing about misfortunes coming about because of non-instalment of advances or other type of credit by the bank's customers known as the credit risks are generally experienced in the money related segment especially the banking sector [30][33]. Credit risk is one of the biggest risks facing the banking industry as a result of defaults in payment by customers.

As per [20] credit hazard is the costliest hazard in micro finance institutions and its impact is more noteworthy when contrasted with other financial risks as it specifically debilitates the dissolvability of money related foundations like the banking sector. The greatness and level of misfortune created by acknowledge hazard when contrasted with other sort of hazard is exceptionally extreme to bring about abnormal state of advance misfortunes and bank disappointment. [12] commented that the foremost causes of banking industry continuous to be directly connected to credit standards for debtors and counterparties, poor portfolio financial risk management, or a lack of devotion to variations in economic or other settings that can lead to a worsening in the credit standing of a bank's counterparties.

Credit creation is the main income generating activity for commercial banks [13]. However, other sources of credit risk exist throughout the activities of a bank, including in the banking book and in the trading book, and both on and off the balance sheet. According to [13], commercial banks are fronting credit risk in numerous transactions, trade financing, 
foreign exchange transactions, financial future, swaps, bonds, equities, option, and in the extension of commitments and guarantees, and the settlements of transaction. But the activity of credit creation encompasses huge financial menaces to both the creditor and the debtor. This is as a results of the debtor not satisfying his or her responsibility as per the contract on due time. This significantly jeopardises the smooth functioning of the bank's business. For commercial banks to endure and uphold satisfactory profit level in this exceedingly competitive industry they require to take undue financial menaces and this has brought about solvency, dissolvability and disappointment of huge number of commercial banks as results of increasing tendency [15].

Several researchers have analysed the association and link among credit risk and financial viability of banks and other micro finance institutions [3][6] [11][28][34]. The management of credit risk should be the forefront of every bank so as to maintain financial sustainability and attaining more customers. According to some researchers, there has been an increased in the number of bank problems in both matured and emerging economies [14][16]. These bank's problems mostly are failures and financial distress of banks, and this has resulted in numerous of the banks been closed down by regulatory authorities. In addition [11] and [20] added that the weakness in credit risk management is the main cause for bank's problems.

The Ghanaian financial industry, particularly that of commercial banks and microfinance institutions has been stressed by the crumbling or worsening nature of its acknowledge resources and assets as a consequence of the noteworthy differences in even-handedness market indices, worldwide rise in oil and unexpected deprecation of the Ghanaian Cedis (GHC) against international currencies like the America dollar and British pound [8][1][33]. The poor quality of the commercial banks' advance resources and assets impeded commercial banks to stretch out more credit to the household economy, which antagonistically influences or affects banks performance and economic development.

\section{STATEMENT OF THE PROBLEM}

Credit menace in the financial sector is well-thought-out by many investigators as a tool that can determine the success and failure of financial institutions particularly the banking industry. Credit risk among the banking industry in Ghana has not been given much attention. This was confirmed by a statement made in the annual [9], stating that some commercial banks in Ghana are unable to manage their credit portfolio, as a results of default of payment by customers. In the case of some banks like The Trust Bank (TTB), Amalgamated Bank and Intercontinental Bank, has been recording a low performance in their banking operations due to ineffective management of credit risk [9] [1][33]. As a result, the banks have been merged by strong performing banks in the country like Ecobank, Access Bank, and Bank of Africa. Moreover, according to [33], the banking industry in Ghana has witnessed a worsening asset quality of banks due to weak macroeconomic factors like the depreciation of the local currency, high inflation rate and interest rate, which results in default repayment of loan. It is against this background that the researchers seek to focus on the association between the credit risk and the performance of commercial banks in Ghana.

The study would provide simple guidelines to those concerned with analysis of the financial conditions of Ghana banks. This research work is proposed for the most part to guide bank clients, shareholders and different partners with next to zero learning in money related bookkeeping to furnish them with fundamental devices of budgetary proclamations investigations and to help them discover the monetary strength of their banks. Additionally it is noteworthy in light of the fact that it will help shape strategy bearings of the banks' financial administration.

Furthermore, to academics and investigators, the findings of the research work are expected to contribute to the present works about the association between credit risk and banks' performance, focusing on Ghana. It will guide managers and supervisors in financial institutions particularly the banking industry to know the importance of managing credit risk so as to improve bank's performance. Furthermore, the achievement of this research work will additionally empower the business researchers to gain hand on aptitudes about handling of research work and information examination. This capability will empower the specialist to deal with such related work with a great deal of exactness and capability.

\section{OBJECTIVES OF THE STUDY}

The overall objective of the study was to analyse the association between banks' credit risk and their financial performance, focusing on some selected commercial banks in Ghana. Specifically, the study looked at the succeeding objectives:

i. Ascertain the relationships between non-performing loans ratio and banks performance (profitability)

ii. Examine the relationship of loan and advance to deposit ratio and banks performance (profitability). 
iii. Find out the effect of non-performing loans ratio and loan and advance to deposit ratio on banks' performance (profitability).

\section{RESEARCH QUESTIONS}

The research questions that were formulated were:

i. What is the association between non-performing loans ratio and banks' profitability?

ii. What is the relationship between loan and advance to deposit ratio and banks' profitability?

iii. What is the association between non-performing loans ratio and banks' profitability (ROE)?

iv. What is the relationship between loan and advance to deposit ratio and banks' profitability (ROE)?

V. What is the effect of non-performing loans ratio, and loan and advance to deposit ratio on banks' performance (profitability).

\section{REVIEW OF RELATED LITERATURE}

\subsection{Theoretical Review}

This section gives an overview of hypothetical writing with the perspective of conveying to the fore the different hypotheses of the relationship between credit risk and bank performance. It serves as the foundation for the study which underpins the argument of the study.

\subsubsection{Portfolio Theory and Conventional Technique of Risk Administration}

Ever since the 1980s, commercial banks have effectively connected up-to-date portfolio model to financial menace. Various commercial banks are presently utilising direct and indirect incomes at financial dysfunctions and worth at risk frameworks to deal with their loan cost and market risk experiences.

Notwithstanding the circumstance that credit chance remains the major financial hazard antagonising most commercial banks, the viable of modern portfolio theory to credit chance has slacked [35]. Commercial banks perceive how credit focuses can antagonistically affect monetary execution and viability. Subsequently, various refined establishments are successfully looking for measureable means to pact with credit risk approximation, while information issues continue to be a snag. Precarious advances are been prepared towards crafting instruments that measure financial menace causalities in a financial portfolio setting. Credit subsidiaries are equally been utilised to productively exchange chance while shielding client acquaintances. The blend of the two advancements has invigorated tremendously accelerated advance in supervising credit chance in a financial portfolio situation in the course of current times.

\subsubsection{Financial Resource-by-Asset Strategies}

Customarily, commercial banks have adopted an advantage by-resource strategy to credit chance. Whereas each commercial bank's technique shifts, by and large this approach includes occasionally assessing the credit nature of advances and additional financial experiences, smearing a credit chance ranking, and accumulating the aftereffects of this investigation to distinguish a portfolio's normal misfortunes. The establishment of the financial resource-by-asset strategies is an all-encompassing advance survey and inner credit menace assessment framework. An advance audit and credit chance rating framework empowers administration to distinguish changes in individual credits, or portfolio drifts in an opportune way [4][31]. In view of the aftereffects of its issue advance recognisable proof, advance survey, and credit chance rating framework administration can make vital alterations to portfolio procedures or increment the supervision of credits in an auspicious way.

Financial credit menace is an emerging apprehension, principally in today's financial environment. Businesspersons must take control or adapt strategies to dominate their organisations, appraisal the dangers inborn in both their organisations and ventures and adopt how to best diminish these financial menace. Financial risk can be security linked, budgetary or functional. That is, for each latent financial risk, a persuasive planning of interior strategic financial menace detectors can be actualised to diminish chance. A portion of the techniques in overseeing credit hazard can be the audit the existing procedure of inward financial menace detectors, which give balanced governance to various units or sections of an organisation. In line with security issues, inside financial control strategies can be as rudimentary as actualising a schema of precautionary measures before entering one's working scope [1][19]. Basically, in relation to funds, it can put unique representatives liable for endorsing payments and marking or approving checks. Constraining the extent of councils with internet access get to speaks to another inside financial menace prevention mechanism. This additionally decreases the operational hazard of disproportionately several representatives bypassing state-of-the-art firewalls to lead individual online corporate taking into consideration their respective working schedules.

Another technique is to put in place a financial risk detective mechanism arrangement. Having satisfactory security to protect against financial menace is just a single viewpoint. 
Looking for an innovative approach or mechanism to largely educate is additional key approach to maintain a strategic distance from financial risk. For instance, in the incident that you have a representative on a job ' $\mathrm{A}$ ' and rudely quit without any meaningful warning, it is expected that task accomplishment on employment ' $A$ ' may drive tolerance. This shows that a reasonable financial risk administration plan will accommodate two workers dependably on each occupation. In this way, the second can venture in when the main clears. On the off chance that having twofold scope is impractical, another option is having an additional week after week staff meeting to stay up with the latest [1].

\subsubsection{Financial Collection Strategy}

As indicated earlier, financial resource-by-asset strategy is a basic part to overseeing a financial menace chance, it does not give a total perspective of financial collection loan risk, where the duration of financial menace alludes to the likelihood that real misfortunes surpass predictable misfortunes [17]. Along these lines, to increase more prominent knowledge into financial risk, banks progressively hope to supplement the benefit by-resource strategy with a measurable financial collection audit utilising a credit display. Banks progressively endeavour to address the failure of the financial resourcebyasset methodology to deal with an assessed unforeseen financial misfortune adequately by seeking after a financial collection strategy. A shortcoming with the financial resourceby-asset strategy is that it experiences issues distinguishing and quantifying fixation [17]. Focus financial risk alludes to extra portfolio chance coming about because of expanded presentation to a mortgagor or debtor, or to a gathering of associated defaulters.

\subsubsection{Conventional Financial Strategy}

Generally, it is difficult to separate among the conventional financial strategy and the new methodologies since a considerable lot of the thoughts of customary frameworks or models are utilised as a part of the new frameworks. The conventional financial strategy takes into consideration the interplay of four facets or dimensions of frameworks:

The first and primary model is the master or expert frameworks. In the master framework, the credit choice is left in the care of the branch loaning officer. The officer's ability, decision, and appraisal of specific variables are the significant and critical elements in the choice to allow advances. The advance officer can look at whatever number focuses as would be prudent, however, should incorporate the five Cs (character, credibility, capital, collateral and cycle). Notwithstanding the five Cs, a specialist may likewise mull over the loan cost [19].
The second model is artificial neural systems. Because of the tedious nature and blunder inclined nature of the automated ability framework, numerous frameworks utilise enlistment to deduce the human master's choice procedure. The systems in question have been projected as answers for the issues of the master framework. This framework reproduces the human learning process [22]. It takes in the way of the relationship amongst data sources and yields by over and again examining input/yield data.

The third is internal assessment at banks. Throughout the years, commercial banks have sectioned their respective performing appraisal scoring class, both past and present [2][1]. For instance at each stage, there is dependably a possibility that some financial viability loans or advances will go into non-payment, and that stores ought to be held in contradiction of such credits.

The fourth model considered was credit scoring frameworks. A financial assessment is a amount that depends on a measurable examination of a lender's credit record, and is utilised to speak to the reliability of that individual [36]. A financial assessment is essentially in view of credit report data. Moneylenders, for example, commercial banks utilise credit score indicator ratings to assess the potential financial hazard postured by offering credits to customers and to relieve misfortunes because of awful obligation.

\subsection{Review of Selected Empirical Studies Related to the Research Work}

Financial credit menace is a genuine danger to the execution of commercial banks; thusly different investigators have inspected the effect of credit menace or risk on commercial banks in shifting measurements. For example, [29] assessed the effect of financial risk within the credit activities of commercial banks on the financial viability and performance of Ghanaian commercial banks.

Budgetary proportions as measures of commercial banks' viability and credit risk were gathered from the yearly reports and records of tested commercial banks from 2010-2014 and dissected utilising expressive, connection and relapse procedures. The discoveries uncovered that credit chance significantly affects the financial viability and performance of Ghanaian commercial banks. It reasoned that banks' financial performance is contrarily affected by the levels of advances and advances, non-performing advances and stores in this way presenting them to extraordinary danger of illiquidity and trouble.

In addition, [31] evaluated the impact of credit hazard on the gainfulness of business banks in Kenya. Information on the 
measure of credit, level of non-performing advances and benefits were gathered for a five year period (2004 - 2008). The discoveries uncovered that the main part of the benefits of business banks are not affected by the measure of financial menace and nonperforming advances, in this manner proposing that unlikely factors other than credit and nonperforming advances effect on benefits.

[24] analysed bank financial viability and performance within the sight of risk for commercial banks contemplating the banks' distributional properties of budgetary proportion. The outcomes demonstrated that execution upgrades take after administrative changes and that hazard clarifies contrasts in banks and non-performing credits adversely influence productivity and profit for resources while the capital sufficiency proportion positively affects the net premium edge.

[19] inspected the credit risk effectiveness of 34 Taiwanese business banks over the period 2005-2008. Their research work utilised money related proportion to evaluate the financial menace and advance risk and was broke down utilising sophisticated and complex quantitative statistical tools. Basically, the financial advance menace and considerations within the financial sector were credit chance specialised effectiveness, credit chance allocative productivity, and credit chance cost proficiency. The outcomes demonstrated that just a single bank is effective in a wide range of efficiencies over the assessed periods. In general, the data envelopment analysis comes about show moderately low normal proficiency levels in financial menace or risk methodological adeptness and portioning of non-viable financial advance in 2008. [1] evaluated the effect of bank's particular hazard attributes, and the general keeping money condition on the execution of 43 business banks working in six of the Gulf Cooperation Council nations over the period 19982008. Utilizing settled impact relapse investigation, comes about demonstrated that financial or credit menace is the central point that influence commercial banks' financial viability and performance when benefit is ascertain by profit for resources while the main hazard that influences productivity when measured by profit for value is liquidity chance.

Furthermore, [29], in endeavour to analyse the impact of bank directions, focus, money related and institutional improvement on business banks' edge and productivity in Nigeria for 17 years (1989 - 2005) establish that commercial bank capitalisation and credit chance have meaningful and huge consequence on banks' net premium edge, cost proficiency and financial viability or success. [29] additionally found that advance misfortune arrangement affects nonperforming advances.
In this way, an expansion in advance misfortune arrangement shows an augmentation in financial menace and decay in the financial character of advances thusly influencing bank execution unfavourably. The discoveries additionally demonstrate the extent of advance misfortune arrangements to aggregate credits was factually noteworthy. As the measure of advance misfortune arrangements shows the level of credit hazard, the outcomes guarantees that Nigerian manages an account with higher credit chance tend to display bring down benefit levels. Additionally the discoveries demonstrated that the benefit quality, as measured by the advance misfortune arrangements, adversely impacts on the execution of banks in Nigeria.

[25] examined the association among financial viability of commercial banks and credit chance. It might be surmised from [25] findings that arrival on value and profit for resources both measuring productivity were conversely known with the proportion of non-performing advance to cumulative credit of commercial banks in this manner stimulating to a shrinkage in gainfulness. In looking at the key predictors of financial menace of financial oriented businesses on growing financial sector frameworks contrasted and the formed financial environments, [25] established that direction is overbearing for keeping financial related models or frameworks that suggests multi facets strategies; operational quality is fundamental in the cases of advance predominant banks in rising financial climates. The boosting of advance misfortune arrangement is moreover assumed to be a noteworthy cause of potential credit or financial menace.

In addition, the research work emphasised that financial risk in emerging commercial banks within developing countries is complex than those in developed economies. The majority of the consequences of the written works looked into depends on old information and furthermore a large portion of the works where done outside the shores of Ghana. In perspective of that this review tries to inspect the relationship between credit hazard (utilising non-performing advances proportion and loans and progress to aggregate store apportion) and commercial banks financial viability or performance, using return on equity and return on assets, among some selected commercial banks in Ghana utilising data (annual reports) crossing from 2010 to 2014; including financing cost and company's size as controlling factors.

\subsection{Conceptual Framework of the Study}

The conceptual framework is made up of two main variables: credit risk and bank's performance which is represented by 
profitability. Credit risk of the bank is determined by three indicators which were pooled together. These indicators or ratios are non-performing loan ratio, and advances to credit ratio, and capital adequate ratio. Profitability as a variable was used to represents commercial banks' performance. This was made up of two variables: return on equity and return on asset (See Figure 1).

Figure 1 portrays that credit risk (independent variable) is measured using banks' non-performing advance proportion, investment adequate ratio and loan and advances to credit proportion; and that of bank performance (dependent variable) is measured using banks profitability. Lastly, interest rate and firm's size of the banks are captured in the conceptual framework as controlling variables. The argument of the study is that the various variables under credit risk when perceive or are in positive terms will help boost the profitability of the bank. This dynamic in the long run will help boost the performance of the bank.

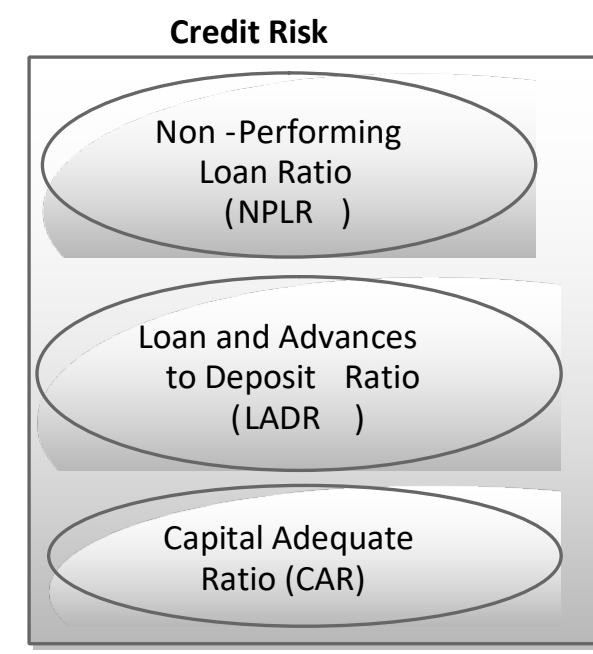

Figure 2.1: Conceptual Framework on Credit Risk and

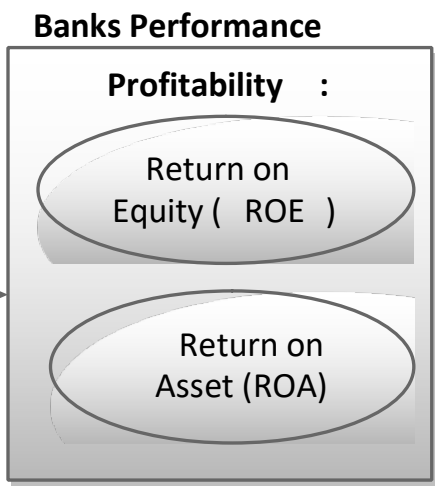

Bank Performance

Source: Author's own construct, 2016.

\section{MATERIALS AND METHODS}

\subsection{Study Design}

According to [27], the selection of research design depends on three situations: the type of research questions, the control the investigator has over actual behaviour or events, and the emphasis on current as opposed to old phenomenon. Thus, the nature of the research questions is critical in determining the methodological approach to be adopted. In conducting research there are three main approaches. The qualitative research approach which aims at providing thick descriptions of the phenomenon being studied, the quantitative approach which lends itself to numerical information and the mixed or combined approach, which is the combination of both qualitative and quantitative approach [21].

Based on the nature of the study, the quantitative approach was adopted for the study in order to help analyse the annual reports of the selected banks. This helped in examining the association that exist between the two main variables with regard to financial or credit menace and financial viability or performance of the selected commercial banks. Therefore, this adopted approach was considered appropriate and desirable based on the objectives and the overall needs of the study.

This methodology concentrates on accomplishing a comprehension of a particular association or occasion, as opposed to surface depiction of an expansive example of a populace. This approach means to give an unequivocal rendering of the structure, request, and expansive examples found among a gathering of members. The quantitative research uses values or numerical figures to represent responses for easy analysis and also to interpret people behaviours in the society. In any case, one noteworthy detriment of utilising this kind of approach is that, it concentrates on a vast group of participants [17]. In addition, the regression model would be used to analyse data that would be gathered from the targeted institutions.

\subsection{Population, Sample and Sampling Procedure}

The population for the research was four banks namely: GCB, UT bank, Zenith Bank and Ecobank plc. The researcher 
intends to examine the relationship between credit risk and bank's performance. The GCB and UT bank were seen as local Ghanaian banks while that of Ecobank plc and Zenith bank were seen as foreign banks in Ghana. These four banks were chosen because they have being appraised among the highest commercial banks in Ghana by the Fitch assessment and The Banker's periodical of July, 2012 [13]. These commercial banks have likewise made the rundown of the initial 25 and 500 commercial banks in Africa and the world separately.

In this way, the example for the research work was the four commercial banks which were chosen utilising the stratified inspecting technique. This inspecting strategy was the best alternative for the populace. In utilising this testing methodology, the lottery strategy for straightforward arbitrary examining procedures was utilised to choose two nearby or local commercial banks and two outside or foreign commercial banks in the wake of stratifying the different banks into two strata. These commercial banks were chosen arbitrarily in light of the fact that they all have the required qualities that the analyst was keen on. The four commercial banks utilised were sufficient to assist the investigator in discovering answers to the different questions detailed from the goals of the work.

\subsection{Measurement of Variables}

Credit risk (independent variable) was measured using nonperforming loan ratio, capital adequate ratio and advances to credit percentage [26]. Basically, these indicators were chosen because literature shows that these indicators are key consideration in improving firms credit risk management [5]. Furthermore, [5] is of the view that bank performance (dependent variable) can be measured using profitability (ROE $\&$ ROA). Interest rate and firm's size of the banks were the two controlling variables.

\subsection{Variables Information \\ 6.4.1. Dependent variable}

The dependent variable was profitability of the various commercial banks selected. This was measured using two main indicators of profitability, that is, Return on Asset (ROA) and Return on Equity (ROE). ROA is the proportion of net income to aggregate assets of the bank. It quantifies the productivity of commercial banks' administration in creating benefit out of its rare assets. The more the measure of profit for resources the better the productivity of the commercial banks' administration, which is useful for the bank. ROE on the other hand represents the other variable used to quantify profitability viability of the various commercial banks. It is a proportion of net pay and aggregate value. It speaks to the rate of return produced by the proprietors' value.

\subsubsection{Independent variables}

Three independent variables were considered in this study. These are non-performing loan ratio (NPLR), loan and advance to deposit ratio (LTDR), and capital adequacy ratio (CAR). NPLR is the most significant marker of commercial banks' financial risk or chance [29]. It is the proportion of non-performing credit to aggregate advance. It speaks to the amount of the commercial banks' advances that are getting to be non-performing, which deals with the degree of financial default menace that the institution maintained. As the measure of this proportion increment, it may lead to negative message for the administration of the institutions since it indicates high likelihood of none recuperating of the financial institutions' significant resource.

LTDR is normally used to assess and quantify commercial banks liquidity. This proportion demonstrates the capacity of commercial banks to withstand store withdrawals and readiness of banks to take care of advance demand by decreasing their money or cash resources. At the point when the commercial banks are more fluid, they can diminish danger of indebtedness. This proportion gives more broad data on the issue store of store since it fails to assess the blend amongst time and request store, and different issues. All things being equal, LTDR can be utilised as a valuable device for surveying commercial banks' assets that can easily be converted to cash.

CAR on the other hand decides the strength of the banking sector to withstand stuns to commercial banks' monetary record. The CAR as measured by the proportion of financial risk weighted cash-flow to risk weighted resources expanded to $18.6 \%$ percent at the end of 2012 from 17.4 percent at the end of 2011, supported by another contestant into the banking industry in December 2012. Be that as it may, the proportion of financial risk resources for aggregate resources declined from 68.8 percent at end 2011 to 67.6 percent at end of 2012 . Level 1 CAR, which was 15.5 percent at the end of 2011, expanded to 16.4 percent at the end of 2012. The CAR was well over the 10 percent prudential and statutory prerequisites, showing a very much promoted and well managed banking framework, with regard to commercial banks, in Ghana.

\subsection{Sources of Data}

The information gathered were fundamentally quantitative that were gotten from the selected commercial banks' annual financial statements and reports, in hardcopy form. This means that the research work wellsprings of information were 
prevalently auxiliary. They were information gathered from the four commercial banks' archives traversing more than five years (2010 - 2014). Likewise industrial midpoints of commercial banks from 2010 - 2014 were additionally utilised where figures were accessible. At long last information issued by ISSER on the condition of the Ghanaian financial climate amid the five years period $(2010-2014)$ of the extent of the examination were additionally valuable.

\subsection{Ethical Considerations}

To satisfy moral and ethical issues related to this research work, an introduction letter was first written by the researcher and approved by the supervisor to acquaint the researcher with the four selected commercial banks. To accumulate information from the selected commercial banks, consent was looked for from the administrators of the banks. An exploration is relied upon to be free from any inclinations and it must be experimentally stable and detailed truly, altogether and totally [32]. Administrators of the four commercial banks were educated about the motivation behind the research work and what target it tried to accomplish. This study and its related philosophy clung to these moral contemplations. A hierarchical passage convention was seen before the information were gathered. Individual administrators contacted were educated of the purpose behind the entire practice and the enormous advantage their respective banks would infer if the examination was completed effectively.

\subsection{Data Analysis and Processing}

The research work made use of quantitative statistical based way to deal with break down the information got from the commercial banks' records. This was on the grounds that the monetary proclamations of the banks were measurable in nature. This aided in showing the data the review required logically which help pondering confirmation. It permits in portraying the information, making correlations, understanding causality, surveying validity of information and investigation. Besides, the said strategy bests compose, and summarises the data into proportions with the end goal that outcome were effectively imparted, and comprehended by individuals who require it.

The study adopted descriptive and inferential measurements to analyse the data. The study made use of board information relapse investigation to examine the information which were gathered from the commercial banks. This implies, there is a dependent and independent variables in the framework or model. The study did not build up another model rather embraced a framework or conceptual model which in the past utilised by different analysts. The regression output was acquired by utilising Predictive Analytic Software (PASW)
Version 21.0. Furthermore, the study utilisedMicrosoft Excel to affirm the precision of the outcomes.

The adopted regression model has been utilised by numerous business researchers [29][31][33] to look at the relationship between financial or credit menace and financial viability or performance within the commercial banking institutions. Early empirical research work have shown or uncovered that the facets or dimensions of profitability is ROE [Net Income $\div$ Total Shareholders' Equity] and for credit risk are NPLR [Non-performing Loans $\div$ Total Loans] and CAR [(Tier I + Tier II) $\div$ Risk Weighted Assets] individually. Besides, the coefficient parameters were assessed utilising summed up strategy for minute. This system is helpful to wipe out the econometric supposition issue.

As showed before, the information gathered were for the times of 2010 - 2014 from the financial yearly publications and financial records of the chose commercial banks. These documents were retrieved in hard copies from the selected banks. The information incorporate time arrangement and cross segment on advances, non-performing loan, add up to stores, profit after tax and aggregate resources of the tested banks. In this review the proportion of non-performing advance and proportion of total advance to total store were utilised as markers of credit hazard while ROA and ROE were pointers of bank profitability which represents performance. Inferential statistical tools such as Pearson product moment correlation, and linear multiple regression analysis were utilised further to handle the stated research questions.

\subsection{Model Specification}

The current research work made use of a rigorous quantitative framework previously used by [31] in his research work that focused on credit and financial related risk and commercial banks' performance in Nigeria. [5] made use of ROA as an output variable in their framework, but this study used both ROA and ROE. These facets of commercial banks' profitability are the most used dimensions of profitability in two different frameworks. This shows that the output variable which is profitability was measured using ROA and ROE. The independent or predictor variable, that is credit or financial risk, was also measured by the ratio of NPLR and LTDR. In order to justify for latent variations on profitability by credit risk mechanisms used in the conceptual framework, error terms were included in the framework. Also two controlling variables were introduced, which are interest rate and firm's size. Below generalised least square model will be estimated using the generalised least square estimation:

Model 1: $\mathrm{ROA}=\beta 0+$

$\beta 1 N P L R t+\beta 2 L T D R t+\varepsilon t$ 
Model 2: $\quad \mathrm{ROE}=\beta 0+$

$\beta 1 N P L R t+\beta 2$ LTDRt $+\varepsilon t$

$\varepsilon t=$ error term per time $(\mathrm{t})$, which is independently and individually distributed with zero mean. $\beta 0=$ Constant term/constant parameter.

$\beta 1-\beta 2=$ Coefficients of the independent variables.

$\mathrm{B} 1<0, \beta 2<0, \beta 3>0 \& \beta 4>0$

$\mathrm{ROA}=$ Ratio of profit after tax to total assets.

$\mathrm{ROE}=$ Ratio of net income to total equity

NPLRt $=$ Ratio of Non-performing loan to loan and Advances per time $(\mathrm{t})$

LTDRt $=$ Ratio of Loan and Advances to Total deposit per time $(\mathrm{t})$.

\section{Results and Discussion}

\subsection{Preliminary Analyses of the Study}

This section deals mainly with the preliminary analyses of the data collected from the four banks. The variables considered were three independent variables (nonperforming loan ratio, loan advances to deposit ratio, and capital adequate ratio) and two dependent variables (return on asset and return on equity). These variables were analysed using descriptive statistics.

\subsubsection{Non-Performing Loan Ratio (NPLR)}

The first variable the preliminary analysis considered was NPLR which is a significant marker of commercial banks financial risk [29]. It is the proportion of non-performing credit to aggregate advance. It speaks to the amount of the banks' advances and advances that are getting to be nonperforming, which assesses quantitatively the degree of financial default chance that the commercial banks managed. As the measure of this proportion increment, it will drive unfortunate note for the administrators of the financial institutions since it indicates preponderance likelihood of none recouping of the institutions real resource. Table 4.1 shows the details of NPLR position of the four banks within the time frame stipulated.

Judging from the NPLR in Table 4.1, GCB was of its highest in 2011 when the bank recorded 26\% and lowest in 2014 at $10 \%$. With regard to EcoBank plc, it registered 15\% in 2010 as highest NPLR, four percent (4\%) as it lowest in 2014. Zenith bank and UT bank recorded inconsistent rates from 2010 to 2014 with regard to increase in NPLR. Relatively, Zenith bank and UT Bank seem to have high level of NPLR. The highest of Zenith bank (31\%) was recorded in 2011 while that of UT bank (24\%) was recorded in 2013. It can be concluded that the four banks were subjected to various level of risk in each of the four years. The data show that EcoBank and GCB bank are doing well with regard to their NPLR.
Table 4.1: Non-Performing Loan Ratio of the Four Banks for $2010-2014$

\begin{tabular}{llllll}
\hline Year & Variable & $\begin{array}{l}\text { GCB } \\
\text { Bank }\end{array}$ & $\begin{array}{l}\text { Zenith } \\
\text { Bank }\end{array}$ & UT Bank & EcoBank \\
\hline 2010 & NPLR & 0.15 & 0.17 & 0.18 & 0.15 \\
2011 & NPLR & 0.26 & 0.31 & 0.14 & 0.06 \\
2012 & NPLR & 0.17 & 0.28 & 0.21 & 0.05 \\
2013 & NPLR & 0.14 & 0.19 & 0.24 & 0.05 \\
2014 & NPLR & 0.10 & 0.14 & 0.17 & 0.04 \\
Average & NPLR & 0.164 & 0.218 & 0.188 & 0.07 \\
\hline
\end{tabular}

Source: 2010 - 2014 Financial Statement for the four banks

This means that as compare to Zenith bank and UT bank, EcoBank and GCB Ltd. as an institution, their loans and advances that are becoming non-performing is minimal and containable. This assesses the degree of credit evasion risk that the commercial banks can sustained. Therefore, in terms of average risk face by the four banks in the area of NPLR from 2010 to 2014 financial year, EcoBank (7\%) seems to be facing less risk than the other banks, followed by GCB bank (16.4\%), UT bank (18.8\%) and Zenith bank (21.8\%). In terms of nonperforming loan within these four banks, EcoBank is doing very well while Zenith bank is not doing well; however, both banks are foreign banks in Ghana.

The findings support the argument that banks with higher ratio of non-performing loan, end up sending corrupt message for administrators of these commercial banks since it shows high likelihood of none recuperating of the banks most significant financial resources [10]. Furthermore, the findings corroborate with the submissions of [4] and [18] who aver that a lower NPLR position of a commercial bank is an indicator to the general public to have confidence in the said bank's credibility and viability. Therefore, customers and investors who are looking for commercial banks that are viable and breaking even in the financial industry may prefer

EcoBank and GCB Ltd ahead of the other two banks (Zenith bank and UT bank). This means that EcoBank is sufficient to meet all maturing secured or unsecured debt obligations due within a stated period. The next item considered in process of analysing the preliminary data was loan advances to deposit ratio. 


\subsubsection{Loan to Deposit Ratio (LTDR)}

Basically, to quantify commercial banks liquidity this research work utilised LTDR which demonstrates the capacity of commercial banks to tolerate payment removals and eagerness of these financial institutions to take care of advance demand by lessening their money resources. At the point when the banks are more fluid, they can diminish danger of bankruptcy. This proportion gives more broad data on the issue deposit of deposit since it fails to assess the blend amongst time and request store, and different issues. All things being equal, LTDR can be utilised as a valuable apparatus for surveying commercial banks liquidity. Table 4.2 illustrates the details of the selected banks with regard to LTDR.

Table 4.2: Loan to Deposit Ratio of the Four Banks for 2010 2014

\begin{tabular}{|c|c|c|c|c|c|}
\hline Year & Variable & $\begin{array}{l}\text { GCB } \\
\text { Bank }\end{array}$ & $\begin{array}{l}\text { Zenith } \\
\text { Bank }\end{array}$ & UT Bank & EcoBank \\
\hline 2010 & LTDR & 0.63 & 0.81 & 0.53 & 0.67 \\
\hline 2011 & LTDR & 0.23 & 0.59 & 0.61 & 0.61 \\
\hline 2012 & LTDR & 0.36 & 0.49 & 0.45 & 0.57 \\
\hline 2013 & LTDR & 0.37 & 0.43 & 0.42 & 0.69 \\
\hline 2014 & LTDR & 0.40 & 0.38 & 0.39 & 0.71 \\
\hline Average & LTDR & 0.398 & 0.540 & 0.480 & 0.650 \\
\hline
\end{tabular}

Source: 2010 - 2014 Financial Statement for the four banks

The concept of LTDR was considered alongside core liquidity of the bank which helps in determining the ability of the bank to tolerate deposit financial drawings and readiness of the banks to meet loan demand. As indicated in Table 4.2, in the years 2010, Zenith bank recorded $81 \%$ as it LTDR while EcoBank, GCB bank and UT bank recorded 67\%, 63\%, and $53 \%$ as it LTDR respectively. However, in the years 2011, 2012, 2013 and 2014 EcoBank recorded highest level of LTDR than the other banks. In 2011, both UT bank and EcoBank recorded $61 \%$ as their highest LTDR. The average ratios show that within the five years interval, EcoBank recorded an average LTDR of $65 \%$, followed by Zenith bank (54\%), UT bank (48\%), and GCB bank (39.8\%) respectively.

Averagely, the results may mean that the foreign banks (EcoBank and Zenith bank) are able to meet deposit withdrawals and also are able to encounter financial advance demand of their customers by decreasing their cash assets in the study period. GCB is the most affected bank with regard to
LTDR since it recorded the lowest average LTDR (39.8\%). This finding may be in line with the comments of the [10] which posits that GCB Ltd have suffered a lot with regard to its liquidity which makes it difficult for the bank to meet all loan demands of its customers. According to [10], this is so because the Tema Oil Refinery (TOR) and other Bulk Purchase Oil Companies in Ghana have borrowed heavily from the bank and are not able to pay because Government of Ghana still owes them as a result of its subsidising policy on crude oil products. This has exposed the bank to liquidity challenge which has boosted its inability to meet all the loan demand of customers.

\subsubsection{Capital Adequacy Ratio (CAR)}

The last independent variable considered was capital adequate ration. This ratio was one of the ratios used to evaluate the risk level of the banks within the period of 2010-2014. The CAR defines the toughness of the banking sector to bear or endure surprises to institution's books. The CAR as determine quantitatively by the proportion of risk-dominated investment to risk-dominated resources. The analyses are presented in Table 4.3.

Table 4.3: Capital Adequacy Ratios of the Four Banks for $2011-2015$

\begin{tabular}{lllllc}
\hline Year & Variable & $\begin{array}{l}\text { GCB } \\
\text { Bank }\end{array}$ & $\begin{array}{l}\text { Zenith } \\
\text { Bank }\end{array}$ & UT Bank & EcoBank \\
\hline 2010 & CAR & 0.10 & 0.19 & 0.24 & 0.21 \\
2011 & CAR & 0.11 & 0.16 & 0.18 & 0.19 \\
2012 & CAR & 0.15 & 0.14 & 0.21 & 0.15 \\
2013 & CAR & 0.21 & 0.15 & 0.19 & 0.16 \\
2014 & CAR & 0.18 & 0.17 & 0.16 & 0.20 \\
Average & CAR & 0.150 & 0.162 & 0.196 & 0.182
\end{tabular}

Source: Annual Reports of the four selected banks (20102014)

As indicated in Table 4.3, the calculation of capital sufficiency proportion is finished by taking proportion of value capital and advances misfortune arrangements less non-performing advances to aggregate resources. Communicated as a rate, the proportion demonstrates the capacity of a bank to withstand misfortunes in the estimation of its financial resources.

$\mathrm{CAR}=[\mathrm{TQ}-\mathrm{RR}]+[\mathrm{LL}-\mathrm{NPL}] \times 100 \%$,

Risk base assets 
Where $\mathrm{TQ}=$ total quality, $\mathrm{RR}=$ revaluation reserves, $\mathrm{LL}=$ loan loss, NPL = nonperforming loan.

Capital ampleness is an impression of the internal quality of a commercial bank, which would stand it in great stead amid the seasons of financial emergency.

Capital sufficiency may have a course on the general financial performance of a commercial bank, such as opening of new branches, crisp loaning in high risk, however, gainful zones, labour enlistment and broadening of business through auxiliaries or through uncommonly assigned branches.

The [10] Capital Adequacy Ratio (CAR) trended from $15.4 \%$ in 2002 to $19.6 \%$ as at June 2012. This trend cause banks to work towards meeting the minimum capital requirement. Table 3 depicts that the position of capital adequacy of Ecobank Ghana, Ghana Commercial bank, Zenith bank and UT bank has been measured. An introspection of the capital adequacy for Ecobank Ghana reveals that the capital adequacy ratio for the 2014 financial year has remained sound overhead the norm of Bank of Ghana i.e. 19.6\%. The ratio increased from $16 \%$ in 2013 to $20 \%$ in 2014 .

However, it decline from $21 \%$ in 2010 to $15 \%$ in 2012 . That of UT ban also decline in 2011, 2013 and 2014 from 24\% to $18 \%, 21 \%$ to $19 \%$, and $19 \%$ to $16 \%$ respectively. This inconsistency is also seen in that of Zenith bank and GCB Limited. However, the average ratios show that the robustness of the four banks in withstanding shocks to their respective balance sheet with regard to their ratio of risk-weighted investment to risk-weighted resources, one may argue that UT bank $(19.6 \%)$ is in the better position to withstand these shocks than any of the three banks, followed by EcoBank (18.2\%), Zenith bank (16.2\%) and GCB Limited (15\%) respectively.

The results show that GCB Limited has less strength in the financial and banking subdivision to endure financial tremors to balance it sheet. This may be due to the current economies challenges or crises in the country, and the challenges the bank may have faced with regard to its lending to TOR and other Bulk Purchase Oil Companies. It can also be attributed to the depreciation of the Ghana cedis and pesewas. It can further be seen from Table 3 that, the CAR for the two foreign banks (EcoBank and Zenith bank) operating in Ghana keep on increasing year after years with regard to 2011 to 2014, which shows a good sign of growth in their performance. However, in the case of the two local banks the situation is different and unsatisfactory. The CAR for the four banks relatively have been good, since the banks have work hard in meeting the minimum capital requirement by means of opening new branches, effective risk management, and deployment of stateof-the-art technology to enhance the banks' operations and productivity.

\subsubsection{Return on Asset (ROA)}

The next preliminary analysis considered was the two dependent variables. The first was ROA. This ratio measures operating profit to total asset. The ratio indicates the benefit obtained by the resource providers and it was the best way to assess profitability. This proportion shows how considerable net revenue was generated/GH $\mathrm{G}$ of assets and is also a key factor for measuring management efficiency. The higher the ratio of ROA the more profitable the bank is. Table 4.4 presents the results of the four banks with regard to their ROA.

Table 4.4: Return on Assets of the Four Selected Commercial Banks

\begin{tabular}{lllllc}
\hline Year & Variable & $\begin{array}{l}\text { GCB } \\
\text { Bank }\end{array}$ & $\begin{array}{l}\text { Zenith } \\
\text { Bank }\end{array}$ & UT Bank & EcoBank \\
\hline 2010 & ROA & 0.02 & 0.08 & 0.07 & 0.09 \\
2011 & ROA & 0.01 & 0.06 & 0.04 & 0.07 \\
2012 & ROA & 0.05 & 0.07 & 0.05 & 0.90 \\
2013 & ROA & 0.14 & 0.05 & 0.02 & 0.09 \\
2014 & ROA & 0.10 & 0.06 & 0.15 & 0.09 \\
Average & ROA & 0.064 & 0.064 & 0.066 & 0.248
\end{tabular}

Source: 2010 - 2014 Financial Statement for the four banks

As contained in Table 4.4, the average ratios of ROA show that Ecobank recorded an impressive ROA ratio $(24.8 \%)$ as compared to UT bank (6.6\%), GCB Ltd (6.4\%), and Zenith bank (6.4\%). In 2010, Ecobank, Zenith bank and UT bank recorded $9 \%, 8 \%$ and $7 \%$ respectively as against that of GCB Ltd (2\%). However, in 2012 Ecobank recorded 90\% which was very significant. In 2013 it recorded 9\% which was repeated in 2014 while UT bank recorded $15 \%$ in 2014. However, in the same year (2014) GCB Ltd recorded 10\% while $6 \%$ recorded by Zenith bank. The results show that within the five years period, Ecobank has been more impressive in terms of ROA than UT bank, Zenith bank and GCB Limited. The scenario in Table 4 implied that for every $\mathrm{GH} \notin 1.00$ assets of Ecobank 9\% was the income generated in 2010 while GCB generated only $2 \%$ which was less than industry average of $1.60 \%$. 
It followed that, averagely, management of Ecobank utilised the assets of their bank to generate more income than UT bank, Zenith bank and GCB Ltd. The percentage showed Ecobank's management efficiency to use asset at its disposal to generate income for their respective banks than the other three banks. This may be due to the fact that government had bigger stake in GCB such that politician with little banking knowledge have been appointed or ensure that their cronies who are not qualified are appointed to manage the bank leading to inefficiency.

A continuous impressive record of ROA is also an indication necessary for the viability of any bank. It can therefore, be concluded that in terms of ROA, Ecobank showed sign of being more profitable than GCB, Zenith bank, and UT bank. Since profitability is key to survival of any entity it followed that, in order of importance, Ecobank and UT bank are more likely to survive than GCB and Zenith bank. While management of this bank (Ecobank) be praised for their remarkable achievement and eager on to do better, GCB, Zenith bank, and UT bank management are advised to review its operational activities to take advantage of its numerous asset base and branches to make higher earring per Ghana cedis of asset.

\subsubsection{Return on Equity (ROE)}

The second dependent variable considered was ROE which is net profit to overall equity. ROE is the greatest significant gauge of commercial banks' profitability and growth prospects. ROE is the degree of return to investors or the percentage return on each GHф of equity spent in the bank. The greater the ratio of ROE the more profitable the bank is. The result on ROE is presented in Table 4.5.

Table 4.5: Return on Equity of the Four Selected Banks

\begin{tabular}{lllllc} 
Year & Variable & GCB & Zenith & UT Bank & EcoBank \\
& & Bank & Bank & & \\
\hline 2010 & ROE & 0.23 & 0.27 & 0.10 & 0.28 \\
2011 & ROE & 0.18 & 0.21 & 0.16 & 0.10 \\
2012 & ROE & 0.19 & 0.35 & 0.16 & 0.48 \\
2013 & ROE & 0.24 & 0.42 & 0.07 & 0.49 \\
2014 & ROE & 0.15 & 0.39 & 0.17 & 0.41 \\
Average & ROE & 0.198 & 0.328 & 0.132 & 0.352 \\
\hline
\end{tabular}

Source: 2010 - 2014 Financial Statement for the four banks
As presented in Table 4.5, the average ratios show that Ecobank registered $35.2 \%$ while Zenith bank registered $32.8 \%$. GCB Limited and Zenith bank also registered 19.8\% and $13.2 \%$ respectively. Specifically, Ecobank registered $28 \%$ in $2010,10 \%$ in $2011,48 \%$ in $2012,49 \%$ in 2013 , and $41 \%$ in 2014 respectively while GCB recorded 23\%, 18\%, 19\%, 24\% and $15 \%$ in similar years. Zenith bank also recorded $27 \%$, $21 \%, 35 \%, 42 \%$ and $39 \%$ respectively within the five year period while UT bank recorded $10 \%, 16 \%, 16 \%, 7 \%$ and $17 \%$ respectively in similar years.

The findings and assessment of the study with regard to the four banks is in line with the view of most researchers [22][31] who posits that ROE is the most important profitability indicator in the financial analysis. ROE shows how well the firm had used resource of owners measured in percentage on each Ghana cedi of equity held in the bank. Comparing the four banks with the industrial average values show that Ecobank and Zenith bank, which are foreign banks in Ghana, have put up yet another remarkable performance by recording higher percentage in terms of ROE.

The implication of the percentages was that shareholders of these two international or non-Ghanaian banks have higher return on their investment than that of GCB and UT bank investors. Since ROE is an indicator of banks profitability and growth potential it followed that potential investors and possibly those of GCB will be wooed to invest in Ecobank and Zenith bank. A continuous trend of this would result to an increase in demand of shares of these two banks (Ecobank and Zenith bank), and its share price on the stock exchange will rise while the share price of the counterpart would fall on the exchange resulting in the fall in capital. It is however, ironical that Ecobank and Zenith bank share prices were rather low on the exchange as indicated in the review. This has posed a topic for further research.

\subsection{Analyses Pertaining to the Research Questions of the Study}

This section presents the results pertaining to the research questions of the study. With the use of the SPSS Version 19.0, Pearson product moment correlation and linear multiple regression analysis were used to analyse the data in order to answer the research questions.

7.2.1 Ascertaining the relationships between nonperforming loans ratio, loan and advance to deposit ratio and banks performance (profitability)

The rational for the first and second purposes of the research work examined the link between non-performing loans ratio, loan and advance to deposit ratio and banks' performance. Four research questions were formulated to tackle these 
objectives. The Pearson product moment correlation was used to analyse the data. This statistical tool was used because the variables were measured numerically. The results are shown in Table 4.6.

Table 4.6: Relationship between Non-Performing Loans Ratio, Loan to Deposit Ratio and Banks Performance (Profitability)

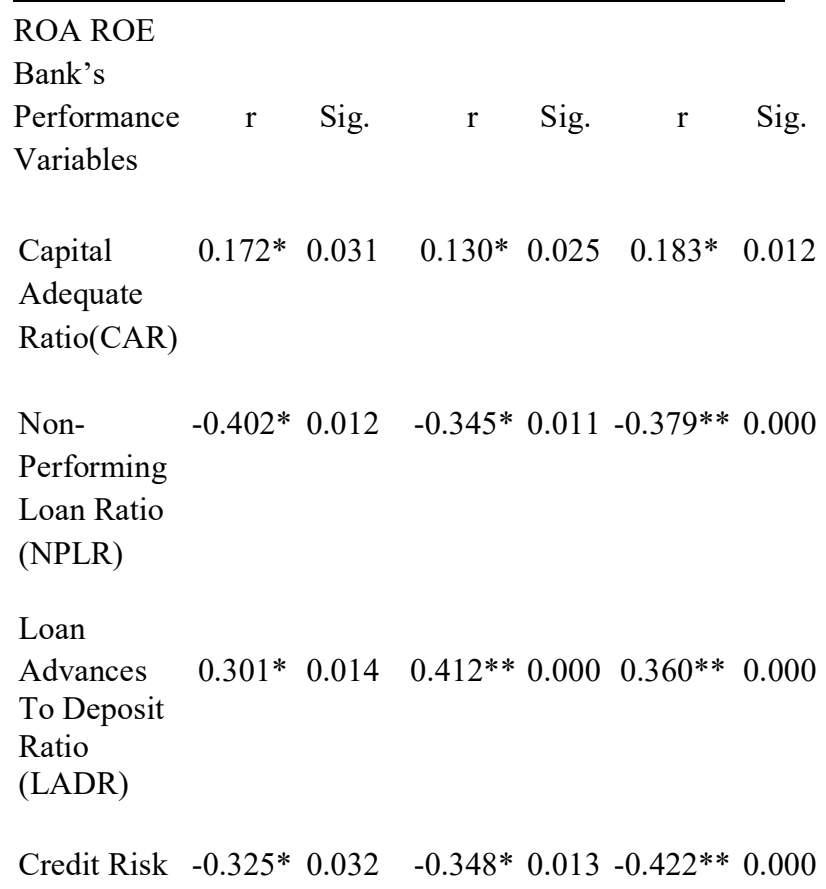

Source: 2010 - 2014 Financial Statement for the four banks **. Correlation is significant at the 0.01 level (2-tailed).

*. Correlation is significant at the 0.05 level (2-tailed). Where $r=$ correlation coefficient

As depicted in Table 4.6, the correlation output between the variables show a statistically significant relationships. Specifically, there was a statistically significant relationship between CAR and ROA $(r=0.172, p<0.05)$, ROE $(r=0.130$, $\mathrm{p}<0.05)$ and performance (profitability) of the banks $(\mathrm{r}=$ $0.183, \mathrm{p}<0.05)$. The relationships between CAR and the other three variables (ROA, ROE and profitability) are weak and positive in nature. This mean that the highest the financial strength of the banking sector to endure financial tremors to banks balance sheet with regard to the four commercial banks the higher the ratio of disposable revenue to overall resources (asset) of the bank, and also the higher the ratio of net income and total equity. This shows that CAR is weakly related in positive terms with the adeptness of the institutions' management in making profit out of their limited financial resources, and the rate of financial yield generated by the owners' equity.
Table 4.6 further shows that there are statistically significant negative but moderate relationships between NPLR and ROA $(\mathrm{r}=-0.402, \mathrm{p}<0.05), \operatorname{ROE}(\mathrm{r}=-0.345, \mathrm{p}<0.05)$ and banks' performance (profitability) $(\mathrm{r}=-0.379, \mathrm{p}<0.01)$. This shows that the higher the NPLR of the four banks, the lesser their profitability with regard to ROA and ROE. Therefore, as these banks' advances are turning into non-performing, the higher are we going to see the financial viability of none recovering of the institutions foremost financial resources or asset. With regard to the third variable, there were statistically significant positive but moderate relationships between LADR and ROA $(\mathrm{r}=0.301, \mathrm{p}<0.05)$, ROE $(\mathrm{r}=0.412, \mathrm{p}<0.01)$, and banks' performance (profitability) $(\mathrm{r}=0.360, \mathrm{p}<0.01)$. Therefore, the higher the ability of the four commercial banks to survive deposit withdrawals and their disposition to encounter advance demand by sinking their financial or cash resources, the higher the profit margin of the banks with regard to ROA and ROE. This shows that when the commercial banks are extra liquid, they can decrease menace of bankruptcy.

Generally, the results in Table 6 show that there is a negative association between credit risk and financial viability (profitability) of the institutions. The correlation coefficients are ROA $(\mathrm{r}=-0.325, \mathrm{p}<0.05)$, ROE $(\mathrm{r}=-0.348, \mathrm{p}<0.05)$, and performance (profitability) $(\mathrm{r}=-0.422, \mathrm{p}<0.01)$. The findings indicate that there will be a decrease in financial viability with every upsurge in the financial menace elements: ratio of non-performing loan, the ratio of advances to overall payments, and the ratio of capital adequacy. This means that the more than banks are subjected to higher credit risk, the lesser they will record or make profit.

The findings are congruent with that of [24] who are of the view that relationship between credit risk exposure and the capital structure, profitability and lending are negative and moderate. Furthermore, the findings are in line with that of [25] who probed the association between performance of a financial institution and its credit or financial risk. [25] found out that financial viability which in turn leads to profitability are inversely associated to the proportion of non-performing loan to overall loan of institutions thereby leading to a weakening in profitability. In examining the key determinants of credit risk of commercial banks on emerging economy banking systems compared with the developed economies, [25] found out that direction is essential for institutions that offer multi facets financial strategies since quality administration is essential when dealing with advance overwhelming institutions in developing financial climates. Meaningful growth in advance misfortune arrangement is also assumed to be a significant and critical cause of possible credit risk within the banking industry. 


\subsubsection{Effect of non-performing loans ratio and loan and advance to deposit ratio on banks' performance}

The rational for the last specific target was to examine the overall consequences of credit risk factors (NPLR, LADR and CAR) on the banks' performance (profitability) which is measured using ROA and ROE. The three credit risk factors were treated as independent variables while profitability (merger of the ROA and ROE figure) was the dependent variable as depicted in the conceptual framework. The linear multiple regression analysis was used in analysing the data in order to answer the research question which was formed from this objective. That is: What is the effect of non-performing loans proportion and advance to deposit ratio on banks' performance?

Using the multiple regression analysis to analyse the data in order to tackle this objective, a diagnostic test was first conducted to check for multicollinearity among the credit risk factors (NPLR, LADR and CAR) or independent variables. This was used to examine the possible detrimental condition where the links between the variables are robust. The SPSS Version 19.0 was used to assess the Variance Inflation Factor (VIF) that measures multicollinearity in the regression model since multicollinearity misleadingly inflates the standard

Table 4.7: Effect of Credit Risk on Banks' Performance (Profitability)

\begin{tabular}{|c|c|c|c|c|c|c|c|}
\hline \multirow[t]{2}{*}{ Variables } & \multicolumn{3}{|c|}{ Unstandardised Standardised } & \multicolumn{4}{|c|}{ Collinearity Coefficients Coefficients Statistics } \\
\hline & B & $\mathrm{SE}$ & Beta & t-value & Sig. & Tolerance & VIF \\
\hline (Constant) & 0.433 & 0.173 & & 2.509 & 0.023 & & \\
\hline NPLR & -0.563 & 0.348 & $-0.405 * *$ & -3.617 & 0.001 & 0.834 & 1.199 \\
\hline LADR & -0.312 & 0.181 & $-0.295 * *$ & -3.171 & 0.001 & 0.824 & 1.213 \\
\hline CAR & -0.301 & 0.728 & $-0.208^{*}$ & -2.413 & 0.035 & 0.930 & 1.075 \\
\hline \multicolumn{8}{|l|}{$\mathrm{R}$} \\
\hline R Square & & & 0.535 & & & & \\
\hline Adjusted & & & 0.394 & & & & \\
\hline R Square & & & 0.358 & & & & \\
\hline
\end{tabular}

errors. Thus, it makes some variables statistically insignificant while they should be otherwise significant.

The VIF was used to measure how much the variance of the estimated coefficients are increases over the case of no correlation among the independent and mediating variables. All the VIF for the independent variables were around 1.075 to 1.213 (See Table 7). None was greater than five (5), which means there was no collinearity associated with the variables. The VIF values were also inversely related to the Tolerance values (VIF $=1 /$ Tolerance). According to Carson et al. (2010), large VIF values (a usual threshold is 10.0 , which corresponds to a tolerance of 0.10 ) indicate a high degree of collinearity or multicollinearity among the independent variables.

In addition, under the collinearity diagnostics table condition index values were all less than 15 indicating no problem. According to [17], a condition index greater than 15 indicates a possible problem while an index greater than 30 suggests a serious problem with collinearity. In all, it is clear that the contribution of the independent variables on the dependent variable largely was not as a result of the strong association among the credit risk factors. Results of the analysis are shown in Table 4.7.

Source: 2010 - 2014 Financial Statement for the four banks $\quad * * \mathrm{p}<0.01 ;{ }^{*} \mathrm{p}<0.05$ Where SE $=$ Standard Error a. Dependent Variable: Banks' Performance b. Predictors: (Constant), CAR, NPLR, and LADR

Table 4.7 shows that all the entered independent variables (NPLR, LADR and CAR) were statistically significant contributors of the banks' performance. As contained in Table 4.7, the variables that contributed meaningfully to the profitability of the bank, in order of importance, are NPLR ( $\square$ $=-0.405, \mathrm{p}<0.01)$, LADR $(\square=-0.295, \mathrm{p}<0.01)$, and CAR $(\square=-0.208, \mathrm{p}<0.05)$. As depicted in 
Table 7, the regression result of the study's model as indicated earlier in chapter three suggests that all the independent variables have negative impact on profitability.

The total contribution of the independent variables (NPLR, LADR and CAR) to the variance in the dependent variable (profitability) was 0.394 with an adjusted R2 of 0.358 . This means that credit risk factors such as NPLR, LADR and CAR influenced or explained about $39.4 \%$ of the variance in the banks' performance (profitability) in terms of ROA and ROE. Therefore, credit risk factors such as NPLR, LADR and CAR have a statistically significant influence on the banks' viability or performance. The parameters show that increase in NPLR decreases profitability by $40.5 \%$ significantly. However, increase in the levels of LADR and CAR significantly decreases profitability of the banks by $29.5 \%$ and $20.8 \%$ respectively. This exposes commercial banks to significant risk level.

The research work demonstrates a direct nonetheless converse association among profitability (ROA and ROE) and credit risk (NPLR, LADR and CAR). The findings are consistent with the findings of Altunbas (2005) who found out that there is a moderate negative and significant relationship between profitability and credit risk. This research work demonstrates that there is a meaningful association between commercial banks' performance (profitability) and their respective financial risks (NPLR, LADR and CAR). Advances and nonperforming loans are real factors in deciding resource nature of an institution. These indicated risk prone factors or variables are critical in deciding the financial viability and profitability of commercial banks in Ghana. In a situation where a commercial bank decides not to adequately deal with its credit and other financial risk, its financial viability and profitability will be shaky. This may mean that the benefit after financial appraisal has remained accessible to the credit arrangement of larger part of the commercial banks in Ghana. In addition, the deposit arrangement additionally influences financial benefit and viability of these commercial banks.

The findings are in line with the assertions of [31] who investigated the impact of credit risk administration, within the banking industry, on the gainfulness and financial robust fullness of commercial banks in Kenya. Information on the measure of credit, level of non-performing advances and benefits were gathered for the period 2004 to 2008. The discoveries uncovered that the greater part of the benefits of business banks are not affected by the measure of credit and non-performing advances, in this manner endorsing that diverse factors other than credit and non-performing advances effect on benefits.
[29] in endeavour to look at the impact of commercial bank controls, fixation, money related and institutional improvement on business banks' edge and gainfulness in Nigeria established that institution capitalisation and credit chance have meaningful and noteworthy consequence on institutions' disposable premium edge, cost effectiveness and productivity. [29] additionally found out that credit misfortune arrangement impacts non-performing advances. Accordingly, an expansion in advance misfortune arrangement shows a boost in credit hazard and failing in the character of advances, therefore, inducing bank financial viability or performance antagonistically.

The findings corroborate with the assertions of [25] who all are of the view that the degrees to which commercial banks deal with their credit chance affect their whole monetary execution or viability. Basically, reasons for extraordinary non-performing advances are, therefore, of relatively low credit hazard administration framework which may influence benefit. In this manner, inability to viably oversee credit hazard generally adds to commercial banks' money related emergency.

Numerous profoundly gainfulness commercial banks in Ghana hold an expansive capacity of branches and deposits. The improvement of advance has remained moderately rapid for as far back as couple of years. Commercial banks in most developing countries such as Ghana turn out to be extra anxious on the grounds that advances are normally among the least secure of all advantages and consequently may hampered their liquidity situation and prompt to trouble. Meaningful credit risk administration result to significant financial viability and profitability. Therefore, it is meaningful for commercial banks to hone sensible financial and credit menace administration to defend their benefits and ensure the financial specialists' interests.

\section{SUMMARY, CONCLUSIONS AND RECOMMENDATIONS}

\subsection{Summary}

Credit risk advanced from an entirely banking or managing an account movement, identified with the nature of advances, to an exceptionally complex arrangement of methods and instruments in the present day budgetary condition. Firms that had been performing great all of a sudden declared vast financial misfortunes because of credit exposures that turned awful, loan cost positions taken or subsidiary exposures that might possibly have been expected to fence monetary record chance. In light of this, commercial banks must be updating 
their credit risk and financial control frameworks periodically to enhance their performance. Specifically, the study examined the relationships between credit risk (NPLR, LADR and CAR) factors and banks' performance (profitability) which is measured using ROA and ROE.

The quantitative approach was adopted for the study in order to help analyse the annual reports of the selected banks. The population for the research was four banks namely: GCB, UT bank, Zenith Bank and Ecobank plc. The stratified sampling procedure that makes use of lottery method of simple random sampling technique was used to handpicked two local banks and two foreign banks in Ghana. The data collected were basically quantitative that were obtained from the banks financial statements for 2010, 2011, 2012, 2013 and 2014. This means that the study sources of data were predominantly secondary. The data were analysed using both descriptive and inferential statistical tools. The key findings that emerged from the data were as follows:

- EcoBank and GCB bank are doing well with regard to their NPLR. This means that as compare to Zenith bank and UT bank, EcoBank and GCB Limited loans and advances that were non-performing were minimal and containable. In in terms of average risk face by the four banks in the area of NPLR from 2010 to 2014 financial year, EcoBank (7\%) seems to be facing less risk than the other banks, followed by GCB bank (16.4\%), UT bank (18.8\%) and Zenith bank (21.8\%).

- Foreign banks (EcoBank and Zenith bank) are able to meet deposit withdrawals and also are able to encounter advance request of their customers by plummeting their liquidity resources in the study period. GCB is the most affected bank with regard to LTDR since it recorded the lowest average

\section{LTDR (39.8\%).}

- With regard to CAR, UT bank (19.6\%) is in the better position to endure financial tremors to its balance sheet with regard to the bank's proportion of risk-weighted investment to risk-weighted resources, followed by EcoBank (18.2\%), Zenith bank (16.2\%) and GCB Limited (15\%) respectively.

- Averagely, management of Ecobank (24.8\%) utilised the assets of their bank to generate more income than UT bank (6.6\%), Zenith bank (6.4\%) and GCB Ltd (6.4\%). In terms of ROA, Ecobank showed sign of being more profitable than GCB, Zenith bank, and UT bank. Since profitability is key to survival of any entity it followed that, in order of importance, Ecobank and UT bank are more likely to survive than GCB and Zenith bank.

- Average ratios of ROE show that Ecobank registered $35.2 \%$ while Zenith bank registered $32.8 \%$. This show that the two foreign banks' (Ecobank and Zenith bank) degree of reoccurrence to owners or the percentage profit on each $\mathrm{GH} \phi$ of parity capitalised in the banks are greater than that of GCB Ltd and UT bank in the study period.

- There were statistically significant relationships between CAR and ROA, ROE and performance (profitability) of the banks $(r=0.183, p<0.05)$. The associations between CAR and the other three variables (ROA, ROE and profitability) were weak and positive in nature.

- There are statistically significant negative but moderate associations between

NPLR and ROA, ROE and banks' performance (profitability).

- Furthermore, there were statistically significant positive but moderate associations between LADR and ROA, ROE, and banks' performance.

- In addition, there was an adverse link with regard to credit risk and profitability.

- Credit risk factors (NPLR, LADR and CAR) were statistically significant contributors of the banks' performance. The variables that contributed negatively and significantly to the profitability of the bank, in order of importance, were NPLR, LADR and CAR.

- The total contribution of the independent variables (NPLR, LADR and CAR) to the variance in the dependent variable (profitability) was 0.394 with an adjusted R2 of 0.358 . This means that credit risk factors such as NPLR, LADR and CAR influenced or explained about $39.4 \%$ of the variance in the banks' performance (profitability) in terms of ROA and ROE.

- There is a direct but inverse relationship between profitability (ROA and

ROE) and credit risk (NPLR, LADR and CAR).

\subsection{Conclusions}

A deliberate way to deal with recognise financial or credit risk stands for a concurred and flawless comprehension of the 
setting in which the financial risk notification is to happen. Credit risk examination then build up a reasonable comprehension of financial risk and includes advance thought of each risk's source result and probability of event. Prevailing procedure, device and practices that demonstrate to limit financial risks or improve positive risk are distinguished and this quality or shortcomings surveyed. From the findings that emerged from this research work, it is reasoned that commercial banks' profitability is conversely impacted by the levels of NPLR, LADR and CAR, accordingly presenting them to incredible financial risk of illiquidity and distress.

In light of the results of financial or bank risk examination, credit risk assessment settles on choice about what dangers require strategic actions, and specific methodologies or mechanisms are needs. The action taking to deal with the challenge is needy upon the conceivable outcomes of the financial menace and the cost of implementing a particular strategy or methodology in dealing with the issues pari passu its manifest advantage. Generally, financial or banking industry in Ghana is moderately perceived to be steady with distinct commercial banks having great credit risk outlines and all-encompassing risk administration systems. The sector has not experienced real financial misfortunes even with the worldwide financial emergencies or crises. The banking industry, however, saw intensifying financial resource nature of commercial banks thus of powerless full scale monetary components like devaluing local currency, high swelling rates and financing costs bringing about great evasion rates.

\subsection{RECOMMENDATIONS}

Regardless of a genuinely decent and viable credit risk administration system set up to sufficiently deal with the risk and improve financial performance, this research work made two or three suggestions which is accepted would help fortify the commercial banks' performance and make it more focused. These are principally identified with credit risk estimation and financial risk incorporation and collection.

The supervision and administration of credit risk in the commercial banks should be vested on a committee in charge of assets and liabilities. Management of the various commercial banks ought to rather guarantee that itemised investigation of advantages and liabilities is done in order to survey the general accounting report structure and financial risk profile of the banks. Furthermore, the committee must ensure that it decides on essential development contour and blend of incremental resources and liabilities, championing financing cost perspective of the institution and settling on the upcoming corporate procedure, review and champion the funding strategy, and choose the exchange evaluating approach of the institution.
Presently, the structure of commercial banks' risk administration system takes into consideration particular risk related choices to be different levels of the bank. Likewise extraordinary methodologies are utilised as a part of dealing with the distinctive financial risk sorts at different units in the bank. Management of the various commercial banks must ensure that they build and maintain a coordinated framework which guarantees an orderly and complete way to deal with overseeing financial and credit risks across the banks' activities.

\section{‡ 9. SUGGESTIONS FOR FURTHER RESEARCH}

The accompanying related study areas can be inquired about to mean the information of what this research work or review has accomplished. To begin with, there is a need to do a relative assessment of the credit risk system and profitability of more international banks including Barclays bank, Standard Chartered bank, SG-SSB bank and so on. Secondly, further research work should be carried out to scrutinise the effect of credit risk on bank's profitability using both quantitative and qualitative data to understand better the dynamics between the two main variables using checklist, questionnaire and interview guide.

Conflict of interest: The authors declare that they have no conflict of interest.

\section{REFERENCES}

[1] Al-Khouri, R. (2011). Assessing the risk and performance of the GCC banking sector, International Journal of Finance and Economics, 65, 7278.

[2] Altunbas, P. (2005). Mergers and acquisitions and bank performance in Europe: The role of strategic similarities. Paris: European Central Bank.

[3] Altunbas, Y., Carbo, S., Gardener, E. P. M., \& Molyneux, P. (2007). Examining the relationships between capital, risk and efficiency in European banking. EuropeanFinancial Management, 13(1), 49-70.

[4] Adrian, T., \& Shin, H. S. (2010). Liquidity and leverage. Journal of Financial Intermediation, 19, 418-437

[5] Anthony, M. C. (2012). Commercial bank risk management: An analysis of the process. Unpublished master's thesis, The Wharton School, University of Pennsylvania, Pennsylvania.

[6] Ayadi, O. F., Adebayo, A. O., \&Omolehin, W. E. (2009). Banking performance measurement in a developing economy. Journal of Banking and Finance, 3(1), 12-23.

[7] Bank for International Settlements. (2011). Global liquidity: Concept, measurement and policy implications. CGFS Papers 45, committee on the global financial system. Retrieved October 28, 2013, from

[8] Bank of Ghana. (2010)Annualreport.http://www.bis.org/publ/cgfs45.pdf

[9] Bank of Ghana (2011). Annual report. Accra: BoG.

[10] Bank of Ghana (2013). Annual report. Accra: BoG

[11] Banker, R., Chang, H., \& Lee, S. Y. (2010). Differential impact of Korean banking system reforms on bank productivity. Journal of Banking and Finance, 34(7), 1450-1460.

[12] Barnes, P. (2005). The analysis and use of financial ratios: A review article. Journal of Business Finance and Accounting, 14(4), 449-461.

[13] Barth, J. R., Caprio, G., \& Levine, R. (2001). The regulation and supervision of banks around the world: A new database. World Bank Policy Research Working Paper Number 2588. 
[14] Basel Committee on Banking Supervision. (2004). Risk management practices and regulatory capital: Cross-sectional comparison. Retrieved October 24, 2014, from www.bis.org.

[15] Boisjoly, R. P. (2009). The cash flow implications of managing working capital and capital investment. Journal of Business \& Economic Studies, $15(1), 98108$.

[16] Brownbrigde, M. (1998). The causes of financial distress in local banks in Africa and implications for prudential policy. New York: UNCTAD.

[17] Carson, D., Gilmore, A., Perry, C., \&Gronhaug, K. (2010). Quantitative marketing research (2nd ed.). London: Sage.

[18] Cetorelli, N., \& Goldberg, L. S. (2012, May). Liquidity management of U.S. global banks: Internal capital markets in the great recession. New York: Federal Reserve Bank of New York.

[19] Cetorelli, N., \& Goldberg, L. S. (2013). Banking globalisation and monetary transmission. Journal of Finance, 67(5), 1811-1843.

[20] Chen, K. H., \&Shimerda, T. A. (2011). An empirical analysis of useful financial ratios. Financial Management, Spring, 51-60.

[21] Chijoriga, M. M. (1997). Application of credit scoring and financial distress prediction models to commercial banks' lending: The case of Tanzania. Unpublished doctoral dissertation, WirtsChaftsnnversitat Wien University, Vienna.

[22] Creswell, J. W. (2010). Quantative inquiry and research design (3rd ed.). London: Sage Publication, Inc.

[23] Demirguc-Kunt, A., \& Huizinga, H. (2010). Financial structure and bank profitability. New York: World Bank.

[24] DeYoung, R., \& Whalen, G. (1994). Banking industry consolidation: Efficiency issues (Working Paper No. 110). A Conference of the Jerome Levy Economics Institute, Office of the Comptroller of the Currency, Washington, DC.

[25] Ezzamel, M., Mar-Molinero, C., \& Beecher, A. (2012). On the distributional properties of financial ratios. Journal of Business Finance and Accounting, 14(4), 463-481.

[26] Fieldsend, S., Longford, N., \& McLeay, S. (2012). Industry effects and the proportionality assumption in ratio analysis: A variance component analysis. Journal of Business Finance and Accounting, 14(4), 497-517.

[27] Frecka, T. J., \& Hopwood, W. S. (2010, January). The effects of outliers on the cross-sectional distributional properties of financial ratios. The Accounting Review, 4(1), 115-128.

[28] Gravetter, F. J., \&Forzano, L. B. (2006). Research methods for the behavioural sciences (2nd ed.). Belmont: Thomson Wadsworth.

[29] Hsiao, H. C., Chang, H., Cianci, A. M., \& Huang, L. H. (2010). First financial restructuring and operating efficiency: Evidence from Taiwanese commercial banks. Journal of Banking and Finance, 34(7), 1461-1471.

Kargi, H. S. (2011). Credit risk and the performance of Nigerian banks. Unpublished master's thesis, Ahmadu Bello University, Zaria.

[30] Khwaja, A., \& Mian, A. (2008). Tracing the impact of bank liquidity shocks: Evidence from an emerging market. American Economic Review, 98, 14131442.

[31] Kithinji, A. M. (2010). Credit risk management and profitability of commercial banks in Kenya. Unpublished master's thesis, School of Business, University of Nairobi, Nairobi.

[32] Malhotra, N. K., \& Birks, D. F. (2007). Marketing research (3rd ed.). Harlow: Dentice Hall/Pearson Education.

[33] Richard, E., Chijoriga, M., Kaijage, E., Peterson, C., \&Bohman, H. (2008). Credit risk management

[34] System of commercial banks in Ghana and Tanzania, International Journal ofEmerging Markets, 3(3), 323-332.

[35] Russell, P., \&Boisjoly, L. (2009). The cash flow implications of managing working capital and capital investment. Journal of Business and Economic Studies, 15(1), 98-108.

[36] Salmi, T., \&Martikainen, T. (2009). A review of the theoretical and empirical basis of financial ratio analysis. The Finnish Journal of Business Economics, 426-448.

[37] Slywotzky, A. J., \&Drzik, J. (2005). Countering the biggest risk of all. Harvard Business Review, 82, 78-88 